\title{
Editorial
}

\section{Eberhard F. Mammen Award Announcements: Part II-Young Investigator Awards}

\author{
Emmanuel J. Favaloro, PhD, FFSc (RCPA) ${ }^{1}$ \\ ${ }^{1}$ Department of Haematology, Sydney Centres for Thrombosis and \\ Haemostasis, Institute of Clinical Pathology and Medical Research \\ (ICPMR), Westmead Hospital, Westmead, Australia
}

Semin Thromb Hemost 2017;43:235-241.

Welcome to another of our Eberhard F. Mammen Award announcements. As noted previously, ${ }^{1-3}$ Thieme, the publisher of Seminars in Thrombosis \& Hemostasis, has created the "Eberhard F. Mammen Excellence in Thrombosis and Hemostasis Awards" in honor of Eberhard Mammen (-Fig. 1) and in recognition of his contribution to this field and to the journal that he founded and steered for over three decades. These awards began in 2009, under two categories; the current award details and conditions are as follows:

- Most Popular Article Award: Awarded to the authors of the most popular articles published in Seminars in Thrombosis $\mathcal{E}$ Hemostasis. The awards are determined by the Editor in Chief on the basis of user statistics from Thieme e-Journals from the preceding 2 years. Prefaces, Errata, Letters to the Editor, Editorials, and previous award winners are excluded from further consideration of these awards, which currently comprise two categories: one for "Open Access" articles and another for a "General Category." There are two major cash prizes of US $\$ 1,000$ for each category. In addition, winners of the "General Category" awards are granted "open access" status for these articles thereafter.

- Young Investigator Award: Best presentation or meeting abstract by a young investigator-as presented or delivered to an international or large regional meeting on a topic related to the fields of thrombosis and hemostasis, and whose subject matter is determined to be in the spirit of Dr. Mammen-up to six cash prizes of US\$1,000 in any year. There are some additional considerations and conditions for the award, and awardees are expected to prepare a review or other paper related to the topic of their presentation (or as otherwise agreed) for publication in Seminars in Thrombosis \& Hemostasis.

Address for correspondence Emmanuel J. Favaloro, PhD, FFSc (RCPA), Department of

Haematology, Sydney Centres for Thrombosis and Haemostasis, Institute of Clinical Pathology and Medical Research (ICPMR), Westmead Hospital, Westmead, NSW 2145, Australia (e-mail: emmanuel. favaloro@health.nsw.gov.au).
Issue Theme Laboratory Assessment of Hemostatic and Anticoagulant Therapy; Guest Editors: Robert C. Gosselin, CLS and Dorothy M. Adcock, MD.

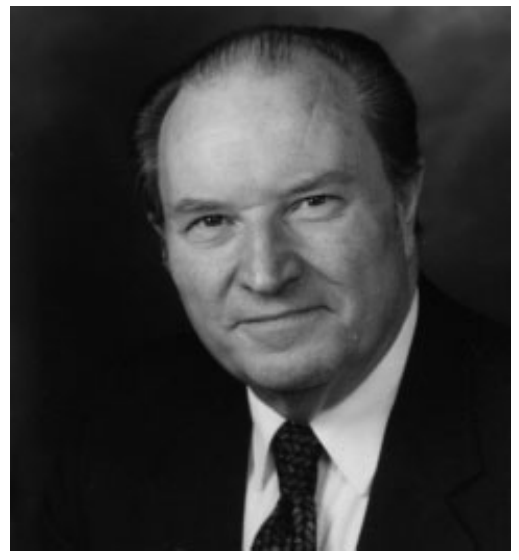

Fig. 1 Eberhard F. Mammen (1930-2008).

Further details of the awards and the award winners are posted online (<http://www.thieme.com/sth $>$ ), and previous award winner announcements are also available in print. $^{4-14}$

The winners of the 2016 Eberhard F. Mammen awards for the most popular articles from Seminars in Thrombosis $\mathcal{E}$ Hemostasis for the period of 2014-2015 inclusive were announced in an earlier issue, ${ }^{14}$ and the awards for the most popular articles from Seminars in Thrombosis $\mathcal{E}$ Hemostasis for the period of 2015-2016 inclusive will be announced in the next issue of the journal. ${ }^{15}$ It is therefore with great pleasure that we would like to announce the winners of the latest round of Young Investigator Awards related to meetings held in the recent past. As this announcement has been delayed, being scheduled for late last year, there are actually more than six awardees, and so this announcement will cover both the 2016 awardees plus one 2017 awardee.

Copyright (c) 2017 by Thieme Medical Publishers, Inc., 333 Seventh Avenue, New York, NY 10001, USA. Tel: +1(212) 584-4662.
DOI http://dx.doi.org/ 10.1055/s-0037-1601383. ISSN 0094-6176. 
Table 1 Latest Young Investigator Awardees

\begin{tabular}{|c|c|c|c|}
\hline Awardee & Current placement & Presentation(s) awarded & Meeting presented \\
\hline Soundarya Selvam & $\begin{array}{l}\text { Pathology and Molecular Medicine, } \\
\text { Queen's University, Kingston, } \\
\text { Ontario, Canada }\end{array}$ & $\begin{array}{l}\text { Blood outgrowth endothelial cells } \\
\text { from type } 3 \text { von Willebrand disease } \\
\text { patients display abnormal angiogenesis }\end{array}$ & \multirow{3}{*}{$\begin{array}{l}\text { ISTH SSC } 2016 \text { (International Society } \\
\text { on Thrombosis and Hemostasis Scientific } \\
\text { and Standardization Committee congress } \\
\text { Montpellier, France, May 2016) }\end{array}$} \\
\hline Vincent Muczynski & $\begin{array}{l}\text { Inovarion/INSERM U1176-HITh; } \\
\text { CHU-Bicêtre, Le Kremlin-Bicêtre, } \\
\text { France }\end{array}$ & $\begin{array}{l}\text { A novel factor VIII-nanobody fusion } \\
\text { protein displaying prolonged half-life } \\
\text { and hemostatic efficacy in vivo }\end{array}$ & \\
\hline Karen Schreiber & $\begin{array}{l}\text { St Thomas' Hospital, } \\
\text { Guy's and St Thomas' NHS } \\
\text { Foundation Trust, UK }\end{array}$ & $\begin{array}{l}\text { HYPATIA-A prospective randomized } \\
\text { controlled trial of HYdroxychloroquine } \\
\text { versus placebo during Pregnancy in } \\
\text { women with AnTIphospholipid Antibodies }\end{array}$ & \\
\hline Adi J. Klil-Drori & $\begin{array}{l}\text { McGill University, Montreal, QC, } \\
\text { Canada; and Jewish General } \\
\text { Hospital, Montreal, Canada }\end{array}$ & $\begin{array}{l}\text { The Risk of Major Bleeding with } \\
\text { Low-Molecular-Weight-Heparins for } \\
\text { Venous Thromboembolism in Dialysis } \\
\text { Patients: The Q-VTE Study }\end{array}$ & \multirow[t]{2}{*}{$\begin{array}{l}2016 \text { ASH (American Society of } \\
\text { Hematology, December 2016, USA) }\end{array}$} \\
\hline Lindsey A. George & $\begin{array}{l}\text { The Children's Hospital of } \\
\text { Philadelphia, } \\
\text { Philadelphia, PA }\end{array}$ & $\begin{array}{l}\text { Adeno-Associated Virus Mediated Gene } \\
\text { Transfer for Hemophilia B Achieves } \\
\text { Sustained Mean Factor IX Activity Levels } \\
\text { of }>30 \% \text { without Immunosuppression }\end{array}$ & \\
\hline Jasmine Wee Ting Tay & $\begin{array}{l}\text { Western Australian Centre for } \\
\text { Thrombosis and Haemostasis } \\
\text { (WACTH), Murdoch } \\
\text { University, Perth, Australia }\end{array}$ & $\begin{array}{l}\text { Validation of plasma miR-494-3p and } \\
\text { miR-365a-3p expression levels as } \\
\text { indicators of thrombotic risk }\end{array}$ & $\begin{array}{l}\text { HAA } 2016 \text { (Haematology Society of } \\
\text { Australia and New Zealand, Australian \& } \\
\text { New Zealand Society of Blood Transfusion } \\
\text { and the Australasian Society of } \\
\text { Thrombosis and Haemostasis; } \\
\text { November 2016, Melbourne, Australia) }\end{array}$ \\
\hline Ivar van Asten & $\begin{array}{l}\text { University Medical Center Utrecht, } \\
\text { Utrecht, The Netherlands }\end{array}$ & $\begin{array}{l}\text { Diagnostic value of a flow } \\
\text { cytometry-based platelet function test } \\
\text { compared with light transmission } \\
\text { aggregometry in patients with unknown } \\
\text { bleeding disorders }\end{array}$ & $\begin{array}{l}\text { ISLH } 2016 \text { (the XXIXth International } \\
\text { Symposium on Technological } \\
\text { Innovations in Laboratory Hematology; } \\
\text { May 2016, Milan, Italy) }\end{array}$ \\
\hline
\end{tabular}

As mentioned previously, the Young Investigator Awards represent winners of the best presentation or meeting abstract by a young investigator-as presented or delivered to an international or large regional meeting on a topic related to the fields of thrombosis and hemostasis, and whose subject matter is determined to be in the spirit of Dr. Mammen. There are additional considerations given that the nominees' presentations are not always seen by all of the possible award nominators, being drawn from the editorial team of the journal. The latest winners are identified below and also listed in - Table 1. The awardees were derived from several meetings.

Soundarya Selvam (-Fig. 2) is a graduate of the University of Western Ontario (BSc (Hon), 2014), and currently a doctoral candidate under the supervision of Dr. Paula James at Queen's University. Her main research interests are von Willebrand factor regulation of angiogenesis and circulating endothelial progenitors in von Willebrand disease and cardiovascular disease. In addition to her research activities, Soundarya also supervises undergraduate students for their fourth-year thesis projects and is an enrichment studies unit instructor engaged in teaching elementary and high school students about human pathologies.

Vincent Muczynski (-Fig. 3) graduated with his PhD from Paris-Sud University in 2011, focusing on the effects of endocrine disruptor exposure on the development of the reproductive function. Next, he moved to the field of hemostasis during a 4-year postdoctoral experience under the mentorship of Dr. Olivier Christophe. During this period, he investigated the mechanisms that regulate the clearance and protection of coagulation factor $\mathrm{X}$. He has been an Inovarion young investigator (since early 2016) in the laboratory of Dr. Cécile Denis. Under the supervision of Dr. Peter Lenting, he aims to help develop bioengineered therapeutic FVIII molecules as alternative options in the treatment of hemophilia A.

Karen Schreiber (-Fig. 4) is a clinical research fellow at the Thrombosis and Haemostasis Centre, St Thomas' Hospital, London. She graduated from Aarhus University in Denmark in 2008 and is currently undertaking her $\mathrm{PhD}$, from the Universities of Copenhagen and London. Her main interests are thrombosis and pregnancy complications in antiphospholipid syndrome. Dr. Schreiber is a board member of the EMEUNET/EULAR, an international network of young rheumatologists; a member of the British Society for Rheumatology working group publishing guidelines on "prescribing anti-rheumatic drugs in pregnancy"; and is managing HYPATIA-a randomized clinical trial on the utility of hydroxychloroquine in mothers with antiphospholipid antibodies.

Adi J. Klil-Drori (-Fig. 5) is a fellow at the Clinical Research Unit of the Jewish General Hospital in Montreal, Canada. He received his MD in 2007 from the Ruth and Bruce Rappaport Faculty of Medicine, Technion-Israel Institute of Technology. After completing internal medicine and hematology training at the Rambam Health Care Campus in Haifa, Israel, he spent 


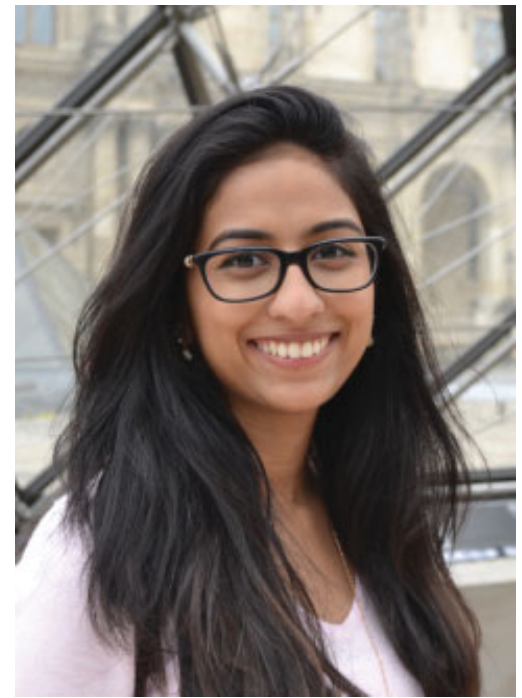

Fig. 2 Young Investigator Award winner Soundarya Selvam.

2 years as a research fellow in clinical epidemiology at McGill University. He holds a Young Investigator Award from the American Society of Clinical Oncology and fellowship awards from the Israeli Cancer Research Foundation and the Canadian Venous Thromboembolism Clinical Trials and Outcome Research Network. His research focus is on drug outcomes in venous thrombosis and hematologic malignancies.

Lindsey George (-Fig. 6) is a hematologist at the Children's Hospital of Philadelphia (CHOP) and Instructor of Pediatrics at the Perelman School of Medicine at the University of Pennsylvania in Philadelphia, Pennsylvania. She completed a pediatric and chief residency at Weill Cornell Medical College and Hematology/Oncology training at CHOP. She initially pursued laboratory training at Dr. Katherine High studying hemophilia gene therapy and has continued basic science training in coagulation biochemistry under the

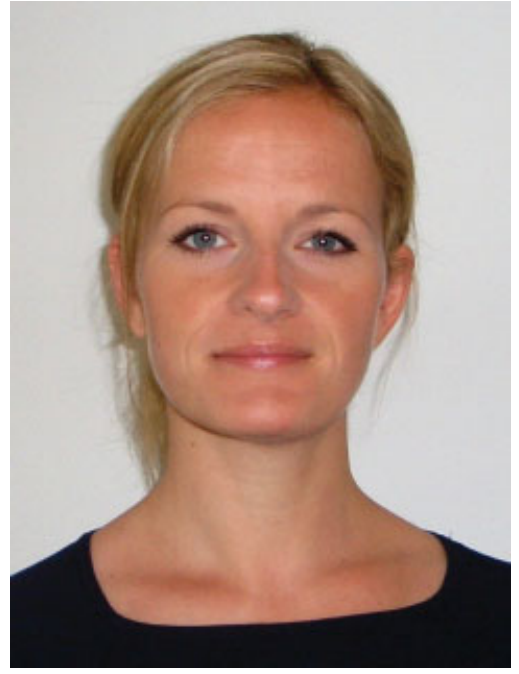

Fig. 4 Young Investigator Award winner Karen Schreiber.

mentorship of Dr. Rodney Camire. She is interested in developing novel therapeutics for hemophilia and is the principal investigator of adeno-associated virus (AAV)mediated gene transfer trials for both hemophilia A and $B$.

Jasmine Tay ( - Fig. 7) is a postdoctoral scientist and the corecipient of the 2015 Caruso Family Postdoctoral Research Fellowship at the West Australian Centre for Thrombosis and Haemostasis located in Murdoch University. She received her PhD from the UWA School of Pathology and Laboratory Medicine in 2013, which investigated the efficacy of androgens in the treatment of poor prognosis breast tumors. Jasmine has continued to pursue her interest in steroid hormone signaling in disease and joined Prof. Ross Baker's Laboratory to study estrogen-regulated microRNAs associated with venous thrombosis during pregnancy and the role of circulating miRNAs in regulating hemostasis.

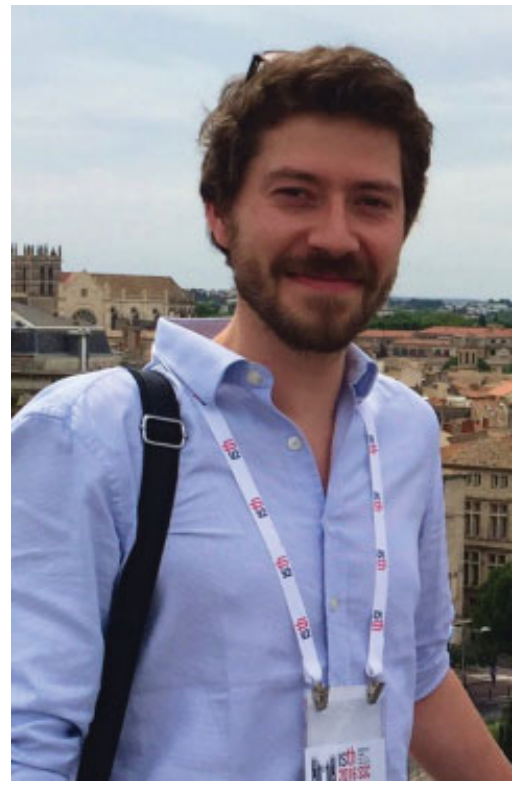

Fig. 3 Young Investigator Award winner Vincent Muczynski.

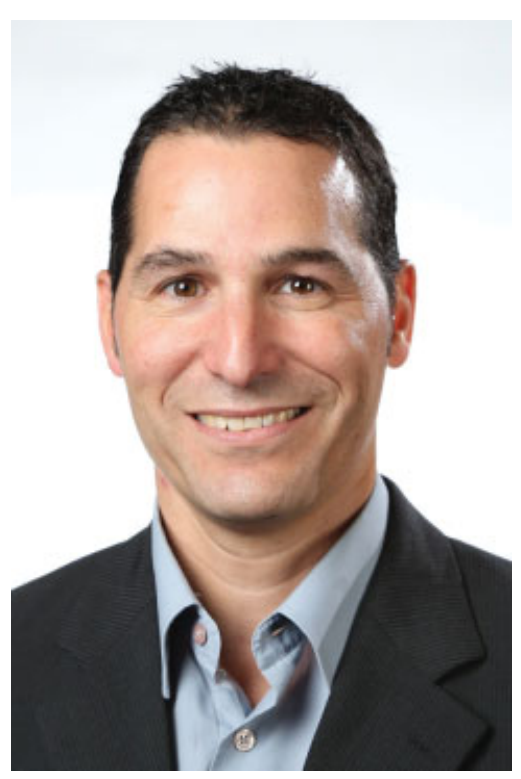

Fig. 5 Young Investigator Award winner Adi J. Klil-Drori. 


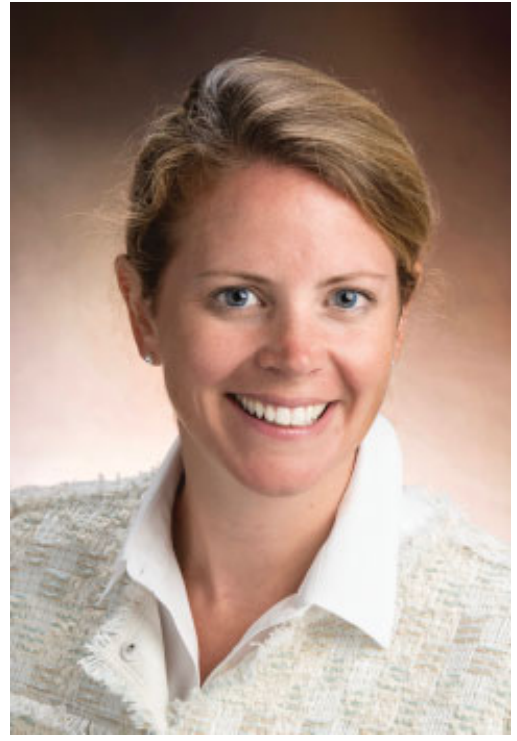

Fig. 6 Young Investigator Award winner Lindsey George.

Ivar van Asten (-Fig. 8) is a PhD student at the Department of Clinical Chemistry and Hematology at the University Medical Center Utrecht in the Netherlands. After his graduation in 2015, he started his PhD study on platelet function disorders and is part of the Thrombocytopathy in the Netherlands (TiN) study group. The main focus of his project is to improve the diagnostic workup in patients with (suspected) platelet function disorders and to identify new mechanisms that contribute to the patient's bleeding phenotype.

All award winners were thrilled to hear that they had been selected to receive an Eberhard F. Mammen Young Investigator Award, and provided the following additional commentary:

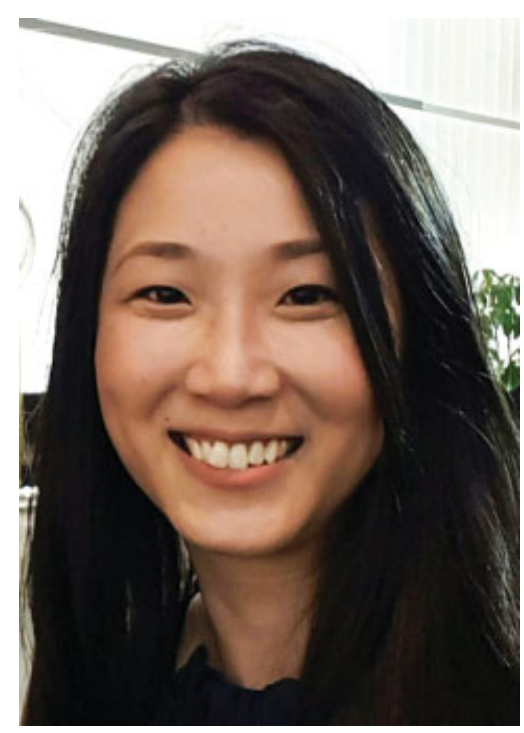

Fig. 7 Young Investigator Award winner Jasmine Tay.

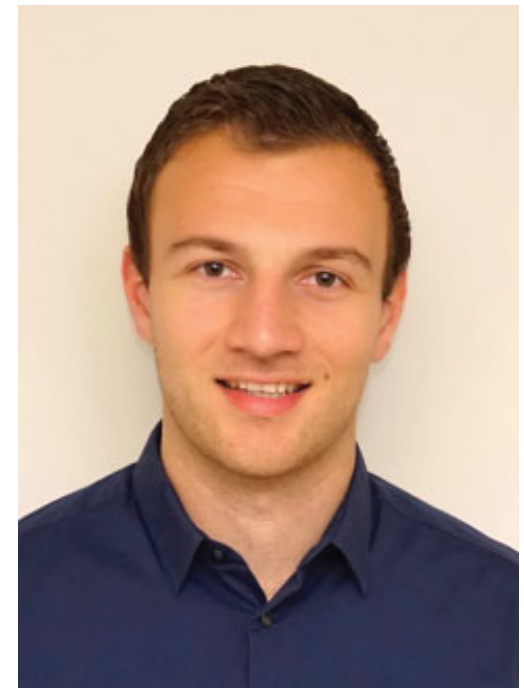

Fig. 8 Young Investigator Award winner Ivar van Asten.

It was with elated surprise and joy that I realized I had been nominated and acknowledged for the 2016 Eberhard F. Mammen Young Investigator Award. This award recognizes a truly collaborative effort and could not have come to fruition without the contributions of Dr. Mackenzie Bowman and Lara Casey. I would also like to extend my gratitude to my supervisor, Dr. Paula James, for giving me the opportunity to explore my research interests in her lab and for her unwavering support.

$$
\text { - Soundarya Selvam (-Fig. 2) }
$$

I am deeply honored to be a recipient of a 2016 Eberhard F. Mammen Young Investigator Award. Beyond the individual recognition, this nomination acknowledges the team effort of all my colleagues in our laboratory. On a daily basis, they are essential actors of the scientific contribution that we attempt to make to the dynamic field of Thrombosis and Haemostasis. I am grateful to them.

$$
\text { - Vincent Muczynski (-Fig. 3) }
$$

I am very excited and honored to have received an Eberhard F. Mammen Young Investigator Award. It is with deepest appreciation that I express my thanks for being chosen to receive this prestigious award. My presentation was an introduction to our "HYPATIA study", which will investigate the role of hydroxychloroquine in pregnant women with antiphospholipid syndrome. This award recognizes not just my efforts, but the efforts of my team and in particular my supervisor Prof. Beverley Hunt who is a true inspiration!

- Karen Schreiber (-Fig. 4) 
Table 2 Young Investigator Awardees from previous years

\begin{tabular}{|c|c|c|}
\hline Awardee & Year awarded & Publication arising \\
\hline Willem M. Lijfering & 2009 & $\begin{array}{l}\text { Lijfering WM, Flinterman LE, Vandenbroucke JP, Rosendaal FR, Cannegieter SC. Relationship between venous and } \\
\text { arterial thrombosis: a review of the literature from a causal perspective. Semin Thromb Hemost 2011;37(8):885- } \\
896\end{array}$ \\
\hline Salley Pels & 2009 & Pels SG. Current therapies in primary immune thrombocytopenia. Semin Thromb Hemost 2011;37(6):621-630 \\
\hline Adam Cuker & 2010 & $\begin{array}{l}\text { Cuker A. Current and emerging therapeutics for heparin-induced thrombocytopenia. Semin Thromb Hemost. } \\
2012 ; 38(1): 31-37\end{array}$ \\
\hline Giridhara Rao Jayandharan & 2010 & $\begin{array}{l}\text { Jayandharan GR, Srivastava A, Srivastava A. Role of molecular genetics in hemophilia: from diagnosis to therapy. } \\
\text { Semin Thromb Hemost 2012;38(1):64-78 }\end{array}$ \\
\hline Timea Szanto & 2010 & $\begin{array}{l}\text { Szántó T, Joutsi-Korhonen L, Deckmyn H, Lassila R. New insights into von Willebrand disease and platelet function. } \\
\text { Semin Thromb Hemost 2012;38(1):55-63 }\end{array}$ \\
\hline Birgitta Salmela & 2010 & $\begin{array}{l}\text { Salmela B, Joutsi-Korhonen L, Armstrong E, Lassila R. Active online assessment of patients using new oral } \\
\text { anticoagulants: bleeding risk, compliance, and coagulation analysis. Semin Thromb Hemost 2012;38(1):23-30 }\end{array}$ \\
\hline Pia Riittaa-Maria Siljander & 2010 & $\begin{array}{l}\text { Aatonen M, Grönholm M, Siljander PR. Platelet-derived microvesicles: multitalented participants in intercellular } \\
\text { communication. Semin Thromb Hemost 2012;38(1):102-113 }\end{array}$ \\
\hline Romaric Lacroix & 2011 & $\begin{array}{l}\text { Lacroix R, Dignat-George F. Microparticles: new protagonists in pericellular and intravascular proteolysis. Semin } \\
\text { Thromb Hemost 2013;39(1):33-39 }\end{array}$ \\
\hline Brad McEwen & 2011 & $\begin{array}{l}\text { McEwen BJ, Morel-Kopp MC, Chen W, Tofler GH, Ward CM. Effects of omega-3 polyunsaturated fatty acids on platelet } \\
\text { function in healthy subjects and subjects with cardiovascular disease. Semin Thromb Hemost 2013;39(1):25-32 }\end{array}$ \\
\hline Neil A. Goldenberg & 2011 & $\begin{array}{l}\text { Bernard TJ, Armstrong-Wells J, Goldenberg NA. The institution-based prospective inception cohort study: design, } \\
\text { implementation, and quality assurance in pediatric thrombosis and stroke research. Semin Thromb Hemost 2013;39 } \\
\text { (1):10-14 }\end{array}$ \\
\hline Vivien Chen & 2011 & $\begin{array}{l}\text { Chen VM. Tissue factor de-encryption, thrombus formation, and thiol-disulfide exchange. Semin Thromb Hemost } \\
\text { 2013;39(1):40-47 }\end{array}$ \\
\hline Joseph E. Italiano Jr. & 2011 & Italiano JE Jr. Unraveling mechanisms that control platelet production. Semin Thromb Hemost 2013;39(1):15-24 \\
\hline Vivian Xiaoyan Du & $2012 / 2013$ & $\begin{array}{l}\text { Du VX, Huskens D, Maas C, Al Dieri R, de Groot PG, de Laat B. New insights into the role of erythrocytes in thrombus } \\
\text { formation. Semin Thromb Hemost 2014;40(1):72-80 }\end{array}$ \\
\hline Andrew Yee & $2012 / 2013$ & Yee A, Kretz CA. Von Willebrand factor: form for function. Semin Thromb Hemost 2014;40(1):17-27 \\
\hline Sarah O’Brien & $2012 / 2013$ & $\begin{array}{l}\text { O’Brien SH. Contraception-related venous thromboembolism in adolescents. Semin Thromb Hemost 2014;40 } \\
\text { (1):66-71 }\end{array}$ \\
\hline Veronica Flood & $2012 / 2013$ & $\begin{array}{l}\text { Flood VH. Perils, problems, and progress in laboratory diagnosis of von Willebrand disease. Semin Thromb Hemost } \\
2014 ; 40(1): 41-48\end{array}$ \\
\hline Julie Tange & $2012 / 2013$ & $\begin{array}{l}\text { Tange JI, Grill D, Koch CD, Ybabez RJ, Krekelberg BJ, Fylling KA, Wiese CR, Baumann NA, Block DR, Karon BS, Chen D, } \\
\text { Pruthi RK. Local verification and assignment of mean normal prothrombin time and international sensitivity index } \\
\text { values across various instruments: recent experience and outcome from North America. Semin Thromb Hemost } \\
2014 ; 40(1): 115-120\end{array}$ \\
\hline Kent Chapman & $2012 / 2013$ & $\begin{array}{l}\text { Chapman K, Yuen S. Therapy for thrombotic thrombocytopenia purpura: past, present, and future. Semin Thromb } \\
\text { Hemost. } 2014 \text { Feb;40(1):34-40. }\end{array}$ \\
\hline Andreas Tiede & 2014 & $\begin{array}{l}\text { Tiede A, Werwitzke S, Scharf RE. Laboratory diagnosis of acquired hemophilia a: limitations, consequences, and } \\
\text { challenges. Semin Thromb Hemost 2014;40(7):803-811 }\end{array}$ \\
\hline Wendy Lim & 2014 & Lim W. Thrombotic risk in the antiphospholipid syndrome. Semin Thromb Hemost 2014;40(7):741-746 \\
\hline Susana Nobre Fernandes & 2014 & $\begin{array}{l}\text { Fernandes S, Carvalho M, Lopes M, Araújo F. Impact of an individualized prophylaxis approach on young adults with } \\
\text { severe hemophilia. Semin Thromb Hemost 2014;40(7):785-789 }\end{array}$ \\
\hline Maria Elisa Mancuso & 2014 & $\begin{array}{l}\text { Mancuso ME, Fasulo MR. Thrombin generation assay as a laboratory monitoring tool during by-passing therapy in } \\
\text { patients with hemophilia and inhibitors. Semin Thromb Hemost } 2016 ; 42(1): 30-35\end{array}$ \\
\hline Coen Maas & 2014 & $\begin{array}{l}\text { Tersteeg C, Fijnheer R, Deforche L, Pasterkamp G, de Groot PG, Vanhoorelbeke K, de Maat S, Maas C. Keeping von } \\
\text { Willebrand factor under control: alternatives for ADAMTS13. Semin Thromb Hemost 2016;42(1):9-17 }\end{array}$ \\
\hline Riten Kumar & 2014 & $\begin{array}{l}\text { Kumar R, Dunn A, Carcao M. Changing paradigm of hemophilia management: extended half-life factor concentrates } \\
\text { and gene therapy. Semin Thromb Hemost 2016;42(1):18-29 }\end{array}$ \\
\hline Juraj Sokol & 2015 & $\begin{array}{l}\text { Sokol J, Skerenova M, Jedinakova Z, Simurda T, Skornova I, Stasko J, Kubisz P. Progress in the understanding of sticky } \\
\text { platelet syndrome. Semin Thromb Hemost 2017;43(1):8-13 }\end{array}$ \\
\hline Ljubica Jovanović & 2015 & $\begin{array}{l}\text { Jovanovic L, Antonijevic N, Novkovic T, Savic N, Terzic B, Zivkovic I, Radovanovic N, Asanin M. Practical aspects of } \\
\text { monitoring of antiplatelet therapy. Semin Thromb Hemost 2017;43(1):14-23 }\end{array}$ \\
\hline Lucia Stanciakova & 2015 & $\begin{array}{l}\text { Stanciakova L, Dobrotova M, Jedinakova Z, Duraj L, Skornova I, Korinkova L, Holly P, Danko J, Stasko J, Kubisz P. } \\
\text { Monitoring of hemostasis and management of anticoagulant thromboprophylaxis in pregnant women with } \\
\text { increased risk of fetal loss. Semin Thromb Hemost 2016;42(6):612-621 }\end{array}$ \\
\hline Tina Biss & 2015 & Biss TT. Venous thromboembolism in children: is it preventable? Semin Thromb Hemost 2016;42(6):603-611 \\
\hline Tobias Fuchs & 2015 & $\begin{array}{l}\text { Jiménez-Alcázar M, Kim N, Fuchs TA. Circulating extracellular DNA - cause or consequence of thrombosis? Semin } \\
\text { Thromb Hemost 2017; DOI 10.1055/s-0036-1597284 }\end{array}$ \\
\hline Jonathan M. Coutinho & 2015 & $\begin{array}{l}\text { Silvis SM, Middeldorp S, Zuurbier SM, Cannegieter SC, Coutinho JM. Risk factors for cerebral venous thrombosis. } \\
\text { Semin Thromb Hemost 2016;42(6):622-631 }\end{array}$ \\
\hline
\end{tabular}


I am thrilled and honored to join a prestigious list of recipients of this award. Our study on the risk of major bleeding with low-molecular-weight-heparins (LMWH) for venous thromboembolism in dialysis patients highlights a vulnerable population with a unique set of bleeding and thrombotic risks. It also reports on realworld utilization of LMWH in this population despite a perceived contraindication, warranting further investigation. I would like to thank my mentor Dr. Vicky Tagalakis for her inspiration and support, and to acknowledge the CanVECTOR Network for the opportunity to be part of a world-class thrombosis research collaboration.

$$
\text { - Adi J. Klil-Drori (-Fig. 5) }
$$

I deeply appreciate this award. It was an honor to present the preliminary results of SPK-9001, a Phase I/II trial of adeno-associated virus mediated factor IX gene transfer for hemophilia B, at the American Society of Hematology scientific plenary. This study builds on two decades of pre-clinical and clinical investigation of gene therapy for hemophilia led by Dr. Katherine High and represents the cumulative efforts of a large group of talented investigators.

$$
\text { - Lindsey George (-Fig. 6) }
$$

It was an incredible surprise to be nominated, and a huge honour to have received the award. This award supports our research investigating microRNAs contributing to pregnancy-associated acquired Protein S deficiency and thrombotic risk, and helps to showcase some of the work being carried out at the Western Australian Centre for Thrombosis and Haemostasis (WACTH) in Murdoch University. I would like to take this opportunity to acknowledge my supervisor Prof. Ross Baker and all my colleagues at WACTH for their ongoing support and contribution to this work.

$$
\text { - Jasmine Tay (-Fig. 7) }
$$

I am absolutely honored being rewarded for one of the Eberhard F. Mammen awards. It feels great that our efforts are being appreciated and it gives extra motivation to move on with our research to improve platelet function diagnostics. I would like to thank all the coauthors for their contributions and special thanks to my supervisors Dr. Rolf Urbanus and Prof. Roger Schutgens.

$$
\text { - Ivar van Asten (-Fig. 8) }
$$

In keeping with previous editorials, I have again reviewed the Young Investigator Awardees from previous years as well as the outcome of their subsequent submissions ${ }^{15-43}$ to Seminars in Thrombosis \& Hemostasis, and as summarized in - Table 2. I previously mentioned my personal gratification that most of the articles from earlier years have subsequently appeared in several annual top 100 listings. $9,10,12,14,44$ of further interest, one of these articles actually won one of the Most Popular Awards in 2014 (within the "Open Access" category) and based on the "most popular" 2012-2013 list. ${ }^{21}$ Also motivating is that a few of the Young Investigator awardees were also included as authors on other contributions to Seminars in Thrombosis \& Hemostasis that were also listed in these most popular listings, including another 2014 Most Popular Award winner. ${ }^{45}$

These findings act to validate the Young Investigator award process, and I look forward to seeing their careers continue to develop. These findings also suggest that future Young Investigator Awardees have very high bars established, and I wish them the best of luck to exceed the precedence set by earlier awardees.

I would like, as always, to congratulate the current Young Investigator Awardees for their awards, and will also take the opportunity to thank previous Young Investigator Awardees for their contributions; these have obviously been well received by readers of this journal. I look forward to reading, and monitoring the future popularity, of the contributions from the latest group of Young Investigators!

\section{References}

1 Favaloro EJ. Editorial. Welcome to a special issue of Seminars in Thrombosis \& Hemostasis-the closing issue for 2008. Semin Thromb Hemost 2008;34:693-696

2 Favaloro EJ. A tribute to Eberhard F. Mammen, M.D. (1930-2008). Semin Thromb Hemost 2008;34(8):703-707

3 Favaloro EJ. Editorial. Welcome to the first issue of Seminars in Thrombosis and Hemostasis for 2009. Semin Thromb Hemost 2009;35:1-2

4 Favaloro EJ. Editorial. Winners of the Inaugural Eberhard F. Mammen Award for Most Popular Article. Semin Thromb Hemost 2009;35:587-590

5 Favaloro EJ. Editorial. 2009 Eberhard F. Mammen Young Investigator Award Winners. Semin Thromb Hemost 2010;36:469-470

6 Favaloro EJ. Winners of the 2010 Eberhard F. Mammen award for most popular article during 2008-2009. Semin Thromb Hemost 2010;36(7):685-692

7 Favaloro EJ. 2011 Eberhard F. Mammen award announcements. Semin Thromb Hemost 2011;37(5):431-439

8 Favaloro EJ. 2012 Eberhard F. Mammen award announcements. Semin Thromb Hemost 2012;38:425-432

9 Favaloro EJ. Eberhard F. Mammen award announcements. Semin Thromb Hemost 2013;39:567-574

10 Favaloro EJ. 2014 Eberhard F. Mammen award announcements: Part I-most popular articles. Semin Thromb Hemost 2014;40(4): 407-412

11 Favaloro EJ. 2014 Eberhard F. Mammen award announcements: Part II-Young Investigator Awards. Semin Thromb Hemost 2014; 40(7):718-723

12 Favaloro EJ. 2015 Eberhard F. Mammen Award Announcements: Part I-Most Popular Articles. Semin Thromb Hemost 2015;41(7): 673-679

13 Favaloro EJ. 2015 Eberhard F. Mammen Award announcements: part II-Young Investigator Awards. Semin Thromb Hemost 2015; 41(8):809-815

14 Favaloro EJ. 2016 Eberhard F. Mammen Award Announcements: Part I - Most Popular Articles. Semin Thromb Hemost 2016;42(4): 325-330 
15 Lijfering WM, Flinterman LE, Vandenbroucke JP, Rosendaal FR, Cannegieter SC. Relationship between venous and arterial thrombosis: a review of the literature from a causal perspective. Semin Thromb Hemost 2011;37(8):885-896

16 Pels SG. Current therapies in primary immune thrombocytopenia. Semin Thromb Hemost 2011;37(6):621-630

17 Cuker A. Current and emerging therapeutics for heparin-induced thrombocytopenia. Semin Thromb Hemost 2012;38(1):31-37

18 Jayandharan GR, Srivastava A, Srivastava A. Role of molecular genetics in hemophilia: from diagnosis to therapy. Semin Thromb Hemost 2012;38(1):64-78

19 Szántó T, Joutsi-Korhonen L, Deckmyn H, Lassila R. New insights into von Willebrand disease and platelet function. Semin Thromb Hemost 2012;38(1):55-63

20 Salmela B, Joutsi-Korhonen L, Armstrong E, Lassila R. Active online assessment of patients using new oral anticoagulants: bleeding risk, compliance, and coagulation analysis. Semin Thromb Hemost 2012;38(1):23-30

21 Aatonen M, Grönholm M, Siljander PR. Platelet-derived microvesicles: multitalented participants in intercellular communication. Semin Thromb Hemost 2012;38(1):102-113

22 Lacroix R, Dignat-George F. Microparticles: new protagonists in pericellular and intravascular proteolysis. Semin Thromb Hemost 2013;39(1):33-39

23 McEwen BJ, Morel-Kopp MC, Chen W, Tofler GH, Ward CM. Effects of omega-3 polyunsaturated fatty acids on platelet function in healthy subjects and subjects with cardiovascular disease. Semin Thromb Hemost 2013;39(1):25-32

24 Bernard TJ, Armstrong-Wells J, Goldenberg NA. The institutionbased prospective inception cohort study: design, implementation, and quality assurance in pediatric thrombosis and stroke research. Semin Thromb Hemost 2013;39(1):10-14

25 Italiano JE Jr. Unraveling mechanisms that control platelet production. Semin Thromb Hemost 2013;39(1):15-24

26 Du VX, Huskens D, Maas C, Al Dieri R, de Groot PG, de Laat B. New insights into the role of erythrocytes in thrombus formation. Semin Thromb Hemost 2014;40(1):72-80

27 Yee A, Kretz CA. Von Willebrand factor: form for function. Semin Thromb Hemost 2014;40(1):17-27

28 O'Brien SH. Contraception-related venous thromboembolism in adolescents. Semin Thromb Hemost 2014;40(1):66-71

29 Flood VH. Perils, problems, and progress in laboratory diagnosis of von Willebrand disease. Semin Thromb Hemost 2014;40(1): 41-48

30 Tange JI, Grill D, Koch CD, et al. Local verification and assignment of mean normal prothrombin time and International Sensitivity Index values across various instruments: recent experience and outcome from North America. Semin Thromb Hemost 2014; 40(1):115-120

31 Chapman K, Yuen S. Therapy for thrombotic thrombocytopenia purpura: past, present, and future. Semin Thromb Hemost 2014; 40(1):34-40

32 Tiede A, Werwitzke S, Scharf RE. Laboratory diagnosis of acquired hemophilia A: limitations, consequences, and challenges. Semin Thromb Hemost 2014;40(7):803-811

33 Lim W. Thrombotic risk in the antiphospholipid syndrome. Semin Thromb Hemost 2014;40(7):741-746

34 Fernandes S, Carvalho M, Lopes M, Araújo F. Impact of an individualized prophylaxis approach on young adults with severe hemophilia. Semin Thromb Hemost 2014;40(7):785-789

35 Mancuso ME, Fasulo MR. Thrombin generation assay as a laboratory monitoring tool during by-passing therapy in patients with hemophilia and inhibitors. Semin Thromb Hemost 2016;42(1): 30-35

36 Tersteeg C, Fijnheer R, Pasterkamp G, et al. Keeping von Willebrand factor under control: Alternatives for ADAMTS13. Semin Thromb Hemost 2016;42(1):9-17

37 Kumar R, Dunn A, Carcao M. Changing paradigm of hemophilia management: extended half-life factor concentrates and gene therapy. Semin Thromb Hemost 2016;42(1):18-29

38 Sokol J, Skerenova M, Jedinakova Z, et al. Progress in the understanding of sticky platelet syndrome. Semin Thromb Hemost 2017;43(1):8-13

39 Jovanovic L, Antonijevic N, Novakovic T, et al. Practical aspects of monitoring of antiplatelet therapy. Semin Thromb Hemost 2017; 43(1):14-23

40 Stanciakova L, Dobrotova M, Jedinakova Z, et al. Monitoring of hemostasis and management of anticoagulant thromboprophylaxis in pregnant women with increased risk of fetal loss. Semin Thromb Hemost 2016;42(6):612-621

41 Biss TT. Venous thromboembolism in children: is it preventable? Semin Thromb Hemost 2016;42(6):603-611

42 Jiménez-Alcázar M, Kim N, Fuchs TA. Circulating extracellular DNA - cause or consequence of thrombosis? Semin Thromb Hemost 2017. doi: 10.1055/s-0036-1597284

43 Silvis SM, Middeldorp S, Zuurbier SM, Cannegieter SC, Coutinho JM. Risk factors for cerebral venous thrombosis. Semin Thromb Hemost 2016;42(6):622-631

44 Favaloro EJ. 2017 Eberhard F. Mammen Award Announcements: Part I - Most Popular Articles. Semin Thromb Hemost 2017. doi: 10.1055/s-0037-1601457

45 Chapman K, Seldon M, Richards R. Thrombotic microangiopathies, thrombotic thrombocytopenic purpura, and ADAMTS- 13 . Semin Thromb Hemost 2012;38(1):47-54 